\title{
Cell wall modification in tobacco by differential targeting of recombinant endoglucanase from Trichoderma reesei
}

\author{
Holger Klose ${ }^{1,2}$, Markus Günl $^{3}$, Björn Usadel ${ }^{2,3}$, Rainer Fischer ${ }^{1,4}$ and Ulrich Commandeur ${ }^{1 *}$
}

\begin{abstract}
Background: The development of transgenic plants as a production platform for biomass-degrading enzymes is a promising tool for an economically feasible allocation of enzymes processing lignocellulose. Previous research has already identified a major limitation of in planta production such as interference with the structure and integrity of the plant cell wall resulting in a negative influence on plant growth and development.

Results: Here, we describe the in planta expression of endoglucanase TrCel5A from the mesophilic fungus Trichoderma reesei with differential intracellular targeting and evaluate its impact on the tobacco cell wall composition. Targeting of the enzyme to the apoplast leads to distinct changes in cell polysaccharides such as glucose level in the matrix polysaccharides (MPS). These effects are combined with severe changes in plant development. Retention of TrCel5A in the endoplasmic reticulum (ER) could avoid visible effects on plant growth under the chosen conditions, but exhibits changes in the composition of the MPS.
\end{abstract}

Conclusions: These results give new insights into the complex interaction of heterologous cellulase expression with cell wall development and it outlines novel promising strategies to engineer plant cell walls for improved biomass processing.

Keywords: Transgenic plant, Mesophilic endoglucanase, Cell wall modification, Differential targeting, Nicotiana tabacum, Trichoderma reesei

\section{Background}

The utilization of lignocellulose, one of the most abundant renewable resources on earth, has the potential to play an important role in energy and commodity supply $[1,2]$. Structural polysaccharides, as part of the lignocellulose and therefore the plant cell wall, represent an extensive source of fermentable carbohydrates [3]. These polysaccharides, consisting of cellulose, hemicellulose and pectin, form a highly cross linked network providing the cell shape tensile properties and hence the structural stability of the plant [4]. These characteristics are also responsible for a major drawback in enzymatic lignocellulose utilization. Plant cell walls have evolved the ability to resist the enzymatic attack from microbes [5]. Therefore, without additional pretreatment the conversion of plant cell walls to fermentable sugar is comparatively slow

\footnotetext{
* Correspondence: commandeur@molbiotech.rwth-aachen.de

${ }^{1}$ Institute for Molecular Biotechnology, RWTH Aachen University, Worringer

Weg 1, 52074 Aachen, Germany

Full list of author information is available at the end of the article
}

and economically unfeasible [5]. To establish economically feasible processes utilizing lignocellulose, the recalcitrance of this substrate has to be overcome [6]. Appropriate modification of plant cell wall polymers can be a promising way to increase the feasibility of plant biomass utilization [7]. Plant cell wall synthesis is regulated by both biosynthesis and degradation with an extensive number of genes involved [8]. Cellulose, the crystalline structure of the microfibrills is synthesized by the cellulose synthase modules (CesA) in the plasma membrane $[9,10]$. In contrast, the synthesis of hemicellulose and pectin begins in the Golgi bodies [11] followed by transport to the apoplastic space where further modification occurs. These are then incorporated into the matrix phase of the cell wall fibers $[12,13]$.

Glycosyl hydrolases (GHs) e.g. endoglucanases (EGs) play an important role in development, remodeling and degradation of different organisms' cell wall mainly plants but also for example fungi. Plant GHs are mostly involved in fiber matrix remodeling or in cell wall plasticity during 
growth and development of the plant [14-16]. Biomass decomposing microorganisms like fungi or Actinobacteria produce these enzymes to convert plant cell wall polysaccharides into monosaccharides for their own metabolism [17].

The recombinant expression of $\mathrm{GHs}$ in planta has been attempted for different reasons, low-cost enzyme production [18,19], modification of starch [20,21] and reducing the recalcitrance of cell walls [22-24].

Promising examples have been described for Acidothermus cellulolyticus endoglucanase E1 in tobacco and maize which resulted in an improved conversion rate of the plant material [23]. Similar advantages have been described for endoxylanase 229B from Dictyoglomus thermophilum [24]. However, already described approaches did not allow a direct comparison between enzymatic effect and plant phenotype, e.g. cell wall structure and degradability [22]. Therefore, additional research with systematic analysis is needed.

Recombinant GHs have been targeted to various subcellular compartments with different results in expression level, stability and impact on the plant growth and development [25-27]. Thermophilic GHs have been found to be expressed with no harmful effect to the plant due to their limited activity at low temperatures [28-30]. Also sequestration by differential targeting and therefore limiting the access of hydrolytic enzymes to the plant cell wall has been addressed but with different effects. E.g. expression of Aspergillus niger ferulic acid esterase in Festuca arundinacea (tall fescue) with localization in ER or Golgi apparatus did show free mono- and dimers of ferulic acid and hence a higher degradability of the plant cell wall [31-33].

Here, we compare the heterologous expression of a mesophilic cellulase from Trichoderma reesei targeted to the ER and apoplast. We demonstrate a correct localization combined with high level expression of the active enzyme in both subcellular compartments. Furthermore, we analyze and correlate the biochemical phenotype of the cell wall derived polysaccharides of both localization variants and evaluate their differences relevant for a subsequent hydrolysis.

\section{Results}

Transgenic tobacco plants with different TrCel5A localization

In order to study the impact of TrCel5A expression with differential subcellular localization, tobacco plants with two different subcellular localizations were analyzed. Tobacco lines expressing TrCel5A localized in the apoplast were taken from a previous study [34].

For plants retaining TrCel5A inside the ER, the endoglucanase gene was fused to the sequence for a C-terminal KDEL signal (Additional file 1 Supplemental figures). Successful cloning was verified by transient expression in $N$. tabacum [35] followed by the detection of the enzyme by Western blot (Additional file 1 Supplemental figures).

Constructs encoding the enzyme with and without the KDEL tag were introduced into tobacco (Nicotiana tabacum SR1) leaf discs by Agrobacterium-mediated transformation [36]. Each generation of transgene plants was screened for the presence of the enzyme by Western blot. Transgene integration was confirmed by genomic PCR and the enzymatic activity was tested by the conversion of 4-methylumbelliferyl $\beta$-D-cellobioside (4MUC) to 4-methylumbelliferon (4MU) and cellobiose (data not shown). Homozygous lines revealing a 3:1 segregation ratio consistent with a single locus insertion were used to produce subsequent generations of plants (Table 1).

Western blots showed that homozygous transgenic plants expressing the secreted version of TrCel5A yielded a recombinant protein with a molecular weight of $\sim 35 \mathrm{kDa}$, similar to that of the native catalytic domain (Figure 1B) consistent with our previous findings that the enzyme undergoes proteolytic cleavage in plant cells [34]. In contrast, homozygous lines expressing TrCel5A with a KDEL tag revealed two fragments. The lighter but more prominent had a molecular weight of approximately $35 \mathrm{kDa}$, similar to the weight of the catalytic domain [37] while the heavier fragment with approximately $42 \mathrm{kDa}$ corresponds to the molecular weight of the holoenzyme. Recombinant protein expression levels in transgenic tobacco plants were determined by measuring the activity of total soluble proteins (TSP) against the substrates azoCMC and 4MUC. T2 plants expressing the secreted version of TrCel5A achieved a specific enzyme activity of up to 1.5 $\mathrm{U} \mathrm{mg}^{-1} \mathrm{TSP}$ on azoCMC (data not shown) and $35 \mathrm{nmol}$ $4 \mathrm{MU} \mathrm{min}^{-1} \mathrm{mg}^{-1}$ on $4 \mathrm{MUC}$ (Figure $1 \mathrm{C}$ ), whereas the ERlocalized version achieved a specific enzyme activity of up to $2.1 \mathrm{U} \mathrm{mg}^{-1}$ on azoCMC and $46 \mathrm{nmol} 4 \mathrm{MU} \mathrm{min} \mathrm{mg}^{-1}$ on 4 MUC (Figure 1C).

\section{Subcellular localization of TrCel5A in tobacco plants}

Localization of TrCel5A was examined in tobacco leaf tissue either by immunostaining with subsequent fluorescence

Table 1 Expression of TrCel5A in transgenic tobacco

\begin{tabular}{lllllll}
\hline Construct & Gene & Subcellular localization & Total plants & Number of events & Expression level T1 & Expression level T2 $^{*}$ \\
\hline TrCel5A $_{\text {ER }}$ & AAA34213.1 & ER & 50 & 39 & $15.9 \pm 11.8$ & $40.8 \pm 5.2$ \\
TrCel5A AP $_{\text {AAA34213.1 }}$ & Apoplast & 35 & 13 & $9.4 \pm 7.5$ & $29.9 \pm 6.4$ \\
\hline
\end{tabular}

Events and plants that produced seed from vectors designed to express endoglucanase from $T$. reesei. The mean value of expression level [nmol $4 \mathrm{MU}$ min $^{-1} \mathrm{mg}^{-1}$ ] of all positive plants for each construct is shown. *Values for second-generation represents the mean of three homozygous lines (T2) with ten samples each are also shown. 

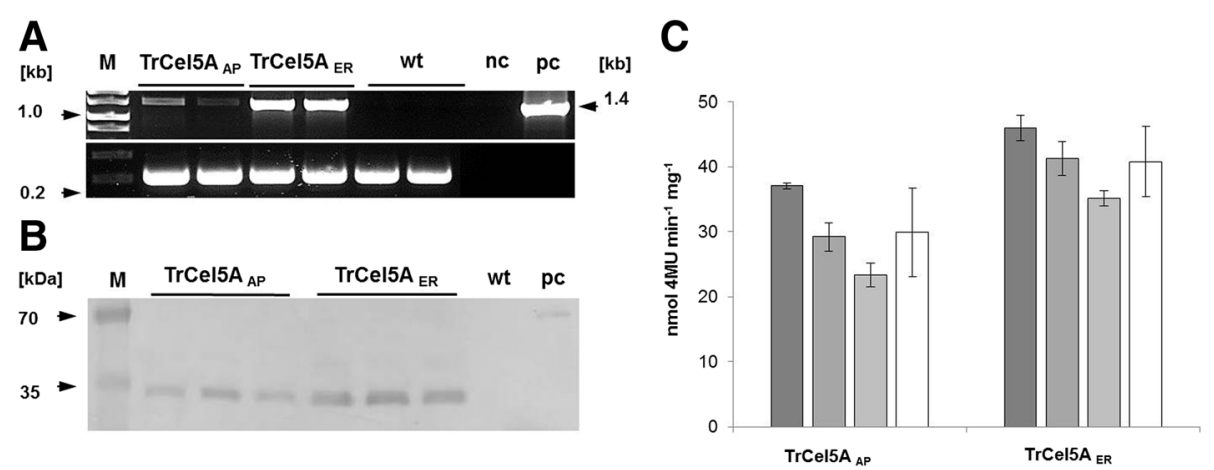

Figure 1 Generation of transgenic tobacco expressing TrCel5A. Genomic PCR of DNA prepared from wt and transgenic plants with primers binding in the CaMV $35 \mathrm{SS}$ expression cassette and below genomic PCR with primers binding in a highly conserved region in the chloroplast genome [38] (A); M, GeneRuler 1 m 1 kb wt: SR1 wild type, nc: $\mathrm{H}_{2} \mathrm{O}$, pc: control plasmid DNA pTRAkc-TrCel5A-ER. Western Blot for recombinant $\operatorname{TrCel5A}$ from three different $\operatorname{TrCe} 5 \mathrm{~A}_{\mathrm{AP}}$ and $\operatorname{TrCel} 5 \mathrm{~A}_{\mathrm{ER}}$ lines (B). Lanes contain $10 \mu \mathrm{g}$ of TSP from transgenic plants; Antibody system used in is MaHis5 /GAM ${ }_{F C}^{A P}$; wt: SR1 wild type, pc: purified His6 tagged Phenylammonium lyase from Zea mays (ZmPAL-His6). In all transgenic lines the degraded TrCel5A is detectable. Additionally in TrCel5A $A_{E R}$ lines also small amounts of the full enzyme are detectable. Expression level of TrCel5A in transgenic tobacco lines was determined by conversion of 4MUC (C). Three independent lines with five plants each were tested (coloured bars). White bars represent the average expression level in $\operatorname{TrCel} 5 \mathrm{~A}_{\mathrm{AP}}$ and $\operatorname{TrCel} 5 \mathrm{~A}_{\mathrm{ER}}$ lines respectively.

or electron microscopy. Stained with either R $\alpha$ Cell and

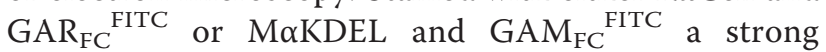
green fluorescence indicated the recombinant enzyme in the transgenic tissue, while no signal was detected in the wild type (wt) control line (Figure 2A-D). Stained with R $\alpha$ Cell and GAR $_{\mathrm{FC}}{ }^{\text {Gold }}$ localization of TrCel5A was confirmed for apoplast and ER by electron microscopy (Figure 2E-H).

\section{Growth characteristics}

The constitutive expression of $\operatorname{TrCel} 5 \mathrm{~A}$ and its localization in the apoplast $\left(\operatorname{TrCel} 5 \mathrm{~A}_{\mathrm{AP}}\right)$ reduced the growth of tobacco plants and significantly delayed their development as described previously [34]. The stem length and germination rate were both reduced. The expression of $\operatorname{TrCel} 5 \mathrm{~A}$ with a KDEL peptide for retention in the ER (TrCel5 $\left.A_{E R}\right)$ resulted in a less significant difference in growth and development (Figure 3). For both constructs, a few transgenic plants displayed a curly and asymmetrical leaf phenotype, and in the $\operatorname{TrCel} 5 \mathrm{~A}_{\mathrm{AP}}$ plants this was accompanied by necrotic areas on the leaf (Figure $3 \mathrm{~A}$ and $\mathrm{B}$ ).

\section{Chemical analysis of tobacco cell walls}

The structural carbohydrate composition of plants expressing differentially-targeted $\operatorname{TrCel} 5 \mathrm{~A}$ was determined in leaf material from six-week-old tobacco plants. Destarched alcohol-insoluble residue (AIR) was hydrolyzed with weak acid [39] and the solubilized carbohydrates were measured as alditol acetate derivatives by GC/MS [40]. The crystalline cellulose content of the tobacco leaf material was determined by Updegraff hydrolysis [41] and the anthrone cellulose assay. Transgenic lines expressing TrCel5A in the apoplast and ER were compared with wt. For transgenic lines accumulating TrCel5A in the apoplast, we could confirm the previous findings showing dramatic changes in the content of crystalline cellulose, which was significantly lower than in wt plants [34]. In contrast, transgenic plants accumulating TrCel5A in the ER did not show such differences (Figure 4A). In addition, the analysis of matrix phase polysaccharides revealed dramatic differences in the monosaccharide composition (Table 2). The TrCel5 $\mathrm{A}_{\mathrm{AP}}$ lines contained less glucose and more xylose. The $\operatorname{TrCel} 5 \mathrm{~A}_{\mathrm{ER}}$ lines showed similar but smaller differences in these sugar levels than the $\mathrm{TrCel} 5 \mathrm{~A}_{\mathrm{AP}}$ lines compared to wt levels. The amount of galactose increased in all transgenic lines. Arabinose and rhamnose levels were lower in the $\mathrm{TrCel} 5 \mathrm{~A}_{\mathrm{AP}}$ lines but no change was found in the level of mannose. Two of three $\operatorname{TrCel} 5 \mathrm{~A}_{\mathrm{ER}}$ lines contained lower levels of xylose, and all three lines contained slightly lower levels of mannose compared to wt plants. A significant reduction in the levels of arabinose and rhamnose was found in only one of the $\operatorname{TrCel} 5 \mathrm{~A}_{\mathrm{ER}}$ lines. The biochemical changes in the cell wall sugars of the $\operatorname{TrCel} 5 \mathrm{~A}_{\mathrm{AP}}$ lines were associated with a growth reduction phenotype, but as discussed above there was no significant visible change in the $\operatorname{TrCel} 5 \mathrm{~A}_{\mathrm{ER}}$ lines despite the modulation of sugar levels. In addition to our previous findings [34], significant changes in the composition of matrix phase polysaccharides could be observed in transgenic lines with $\operatorname{TrCel} 5 \mathrm{~A}$ targeted to the apoplast. In contrast, transgenic tobacco plants targeting TrCel5A to the ER did not show these differences in crystalline cellulose content but also exhibit changes in matrix phase sugar composition.

\section{Hydrolysis of leafy biomass from transgenic tobacco}

To determine the hydrolysis rate of transgenic leaf material, tobacco plants were selected with similar TSP and 

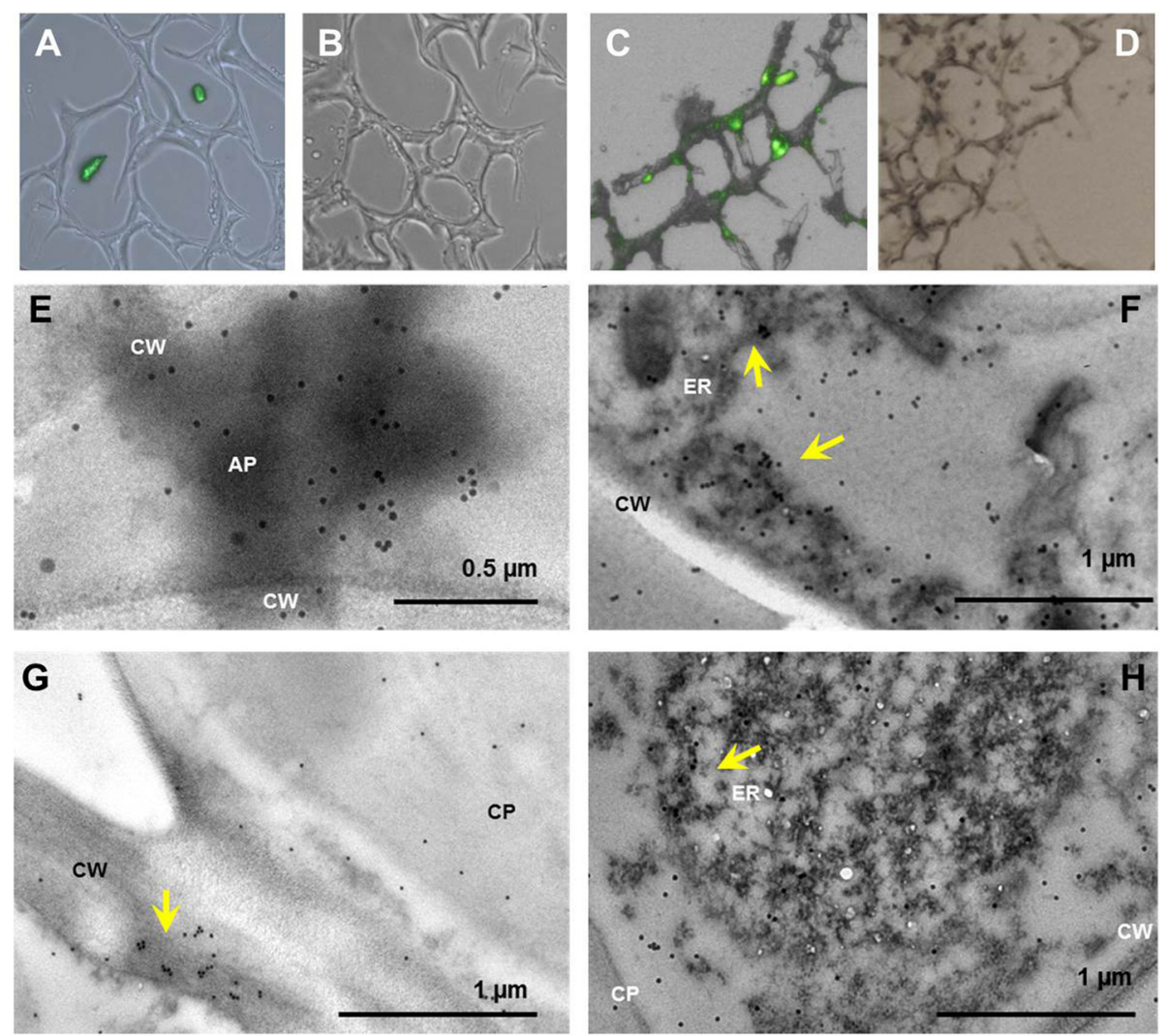

Figure 2 Localization of TrCel5A in transgenic tobacco leaf tissue. Plant tissue expressing $\operatorname{TrCel} 5 \mathrm{~A}$ targeted to the ER (A) and wt (B) were immunostained with the MaKDEL primary antibody and GAM ${ }_{F C}{ }^{\text {FTC }}$. Apoplast targeting was monitored by staining transgenic plant tissue and wt with RaCell primary antibody and GARFC FITC (C-D). Electron microscopy with immunolabeling (RaCell/GAR GCold) indicated localization for TrCel5A inside the apoplastic space or at the cell walls $(\mathbf{E}, \mathbf{G})$ and for $\operatorname{TrCel5} A_{E R}$ inside the ER $(\mathbf{F}, \mathbf{H})$. Arrows mark accumulation of recombinant enzyme.

TrCel5A activity levels (release of 4MU). Different Transgenic lines with both localizations were compared to wt plants. After enzymatic hydrolysis with a commercial cellulase cocktail (Novozymes, Bagsvaerd, Denmark), the remaining crystalline cellulose was determined from the insoluble remnants. In comparison to wt, transgenic leaf material with $\operatorname{TrCel} 5 \mathrm{~A}_{\mathrm{ER}}$ did not show any significant change in the released relative cellulose values or the rate in hydrolysis, independent from the TrCel5A expression level. In contrast, leaf biomass from $\mathrm{TrCel} 5_{\mathrm{AP}}$ lines showed a significantly accelerated hydrolysis after $8 \mathrm{~h}$ (Figure 4). However, after $65 \mathrm{~h}$ the relative amount of solubilized crystalline cellulose $(80 \pm 1 \%)$ did not differ from $\operatorname{TrCel} 5 \mathrm{~A}_{\mathrm{ER}}(79 \pm 3 \%)$ and wt plants $(77 \pm 3 \%)$.

\section{Discussion}

Current research in the area of biofuels aims to achieve the economically feasible production of cellulolytic enzymes for the conversion of lignocellulosic biomass into soluble sugars. Plants offer a relatively inexpensive production platform for industrial proteins $[42,43]$ and therefore plants have been used to express a number of biomass-degrading enzymes [25-27].
Several studies have demonstrated the potential of in planta recombinant cellulases by achieving the accumulation of functional enzymes at high levels $[18,23,44]$. However, several drawbacks are associated with constitutive cellulase expression, including growth inhibition, changes in leaf morphology, loss of cell wall integrity and reduced stress tolerance $[25,44,45]$.

Plants express endogenous GHs that play an important yet barely understood role in cell wall synthesis [46]. Both the overexpression and silencing of these GHs can have a negative impact on growth and cell wall development [14,47].

These issues have been addressed by targeting cell walldegrading enzymes to different subcellular compartments, which can increase the overall enzyme yields $[29,33,48]$ as well as keeping potentially harmful enzymes away from the cell wall $[49,50]$. We therefore established transgenic tobacco lines expressing the $T$. reesei mesophilic endoglucanase TrCel5A retained in the ER and compared them with transgenic lines from a previous study secreting TrCel5A to the apoplast [34].

For transgenic plants, TrCel5A localization was confirmed by immunostaining thin tissue sections, though 

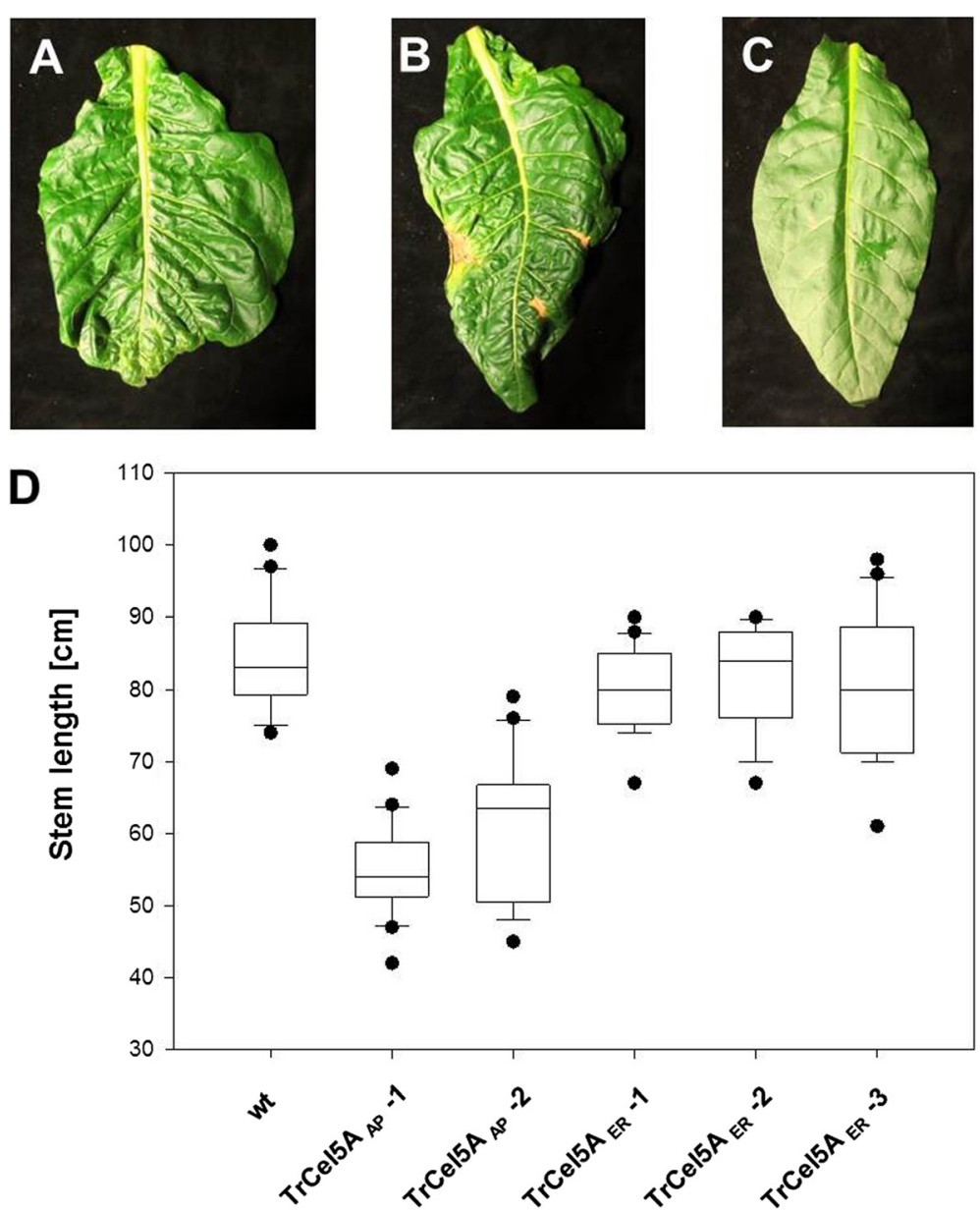

Figure 3 Transgenic tobacco plants expressing TrCel5A. Eight-week-old N. tabacum SR1 wt plants were grown in soil under standard conditions. Twenty plants of each line and wt were monitored on their stem size $\operatorname{TrCel} 5 \mathrm{~A}_{\mathrm{AP}}$ plants showed a significant reduction in size and growth rate, whereas TrCel5 $A_{E R}$ plants were not significantly different from wt (D). The leaf shape of several transgenic plants was altered compared to wt (C). TrCel5A $A_{E R}$ (A) and $\operatorname{TrCe} 5 \mathrm{~A}_{\mathrm{AP}}$ plants (B) displayed a curly leaf phenotype which in the case of $\operatorname{TrCel} 5 \mathrm{~A}_{\mathrm{AP}}$ plants included additional necrotic lesions.
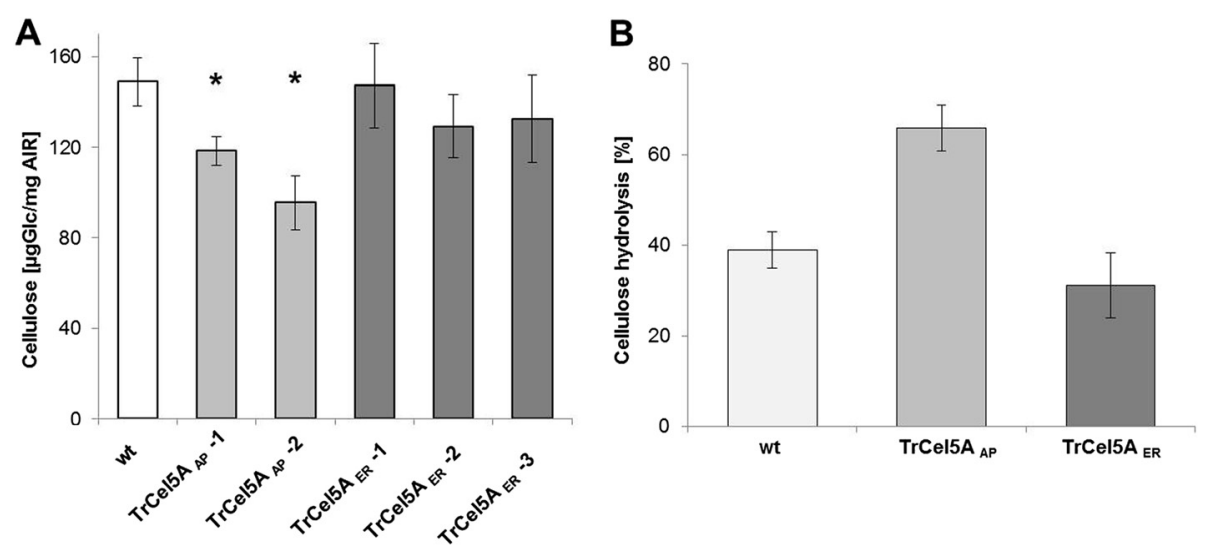

Figure 4 Cellulose content and cell wall convertibility in transgenic tobacco. The crystalline cellulose content and stem length was analyzed in six-week-old wt and TrCel5A transgenic tobacco plants grown in soil. Asterisks indicate a significant decrease $(P \leq 0.01)$ in the crystalline cellulose content for TrCel5 $\mathrm{A}_{A P}$ compared to wt plants whereas TrCel5 $\mathrm{A}_{E R}$ plants show no significant difference (A). Leaf tissue from transgenic tobacco lines TrCel5A $A_{A P}$ and TrCel5AER (B). Samples from both lines expressing $30 \mathrm{mU} / \mathrm{mg}$ TSP (based on 4MUC conversion) were hydrolyzed with the appropriate amount of the commercial cellulase preparation [24]. Digestion was carried out at $55^{\circ} \mathrm{C}$ with constant shaking at $1000 \mathrm{rpm}$. The $\operatorname{TrCel} 5 \mathrm{~A}_{\mathrm{AP}}$ leaves showed higher hydrolysis levels than the TrCel5A $\mathrm{A}_{\mathrm{ER}}$ and wt leaves after $8 \mathrm{~h}$. 
Table 2 Compositional analysis of matrix-phase polysaccharides in different transgenic tobacco lines

\begin{tabular}{|c|c|c|c|c|c|c|}
\hline Line & Arabinose & Glucose & Galactose & Mannose & Rhamnose & Xylose \\
\hline \multirow[t]{2}{*}{$\overline{w t}$} & 20.4 & 23.6 & 16,8 & 6.1 & 17.9 & 13.9 \\
\hline & \pm 2.6 & \pm 8.4 & \pm 2.1 & \pm 1.1 & \pm 2.3 & \pm 1.8 \\
\hline \multirow[t]{2}{*}{$\operatorname{TrCel} 5 A_{A P}-1$} & $14.9^{* *}$ & $10.8^{* *}$ & $32.7^{* *}$ & 5.3 & $14.4^{*}$ & $21.8^{* *}$ \\
\hline & \pm 1.4 & \pm 1.3 & \pm 6.7 & \pm 1.6 & \pm 3.68 & \pm 3.44 \\
\hline \multirow[t]{2}{*}{$\operatorname{TrCel} 5 A_{A P}-2$} & $16.6^{*}$ & $13.9^{* *}$ & $34.1^{* *}$ & 5.0 & $13.4^{* *}$ & $16.9^{* *}$ \\
\hline & \pm 1.9 & \pm 4.7 & \pm 4.7 & \pm 1.2 & \pm 1.7 & \pm 1.9 \\
\hline \multirow[t]{2}{*}{$\operatorname{TrCel} 5 A_{E R}-1$} & 20.7 & $17.9^{*}$ & $27.7^{* *}$ & 5.0 & 16.9 & 13.9 \\
\hline & \pm 1.7 & \pm 2.5 & \pm 2.9 & \pm 0.7 & \pm 1.6 & \pm 1.4 \\
\hline \multirow[t]{2}{*}{ TrCel5A $A_{E R}-2$} & $16.1^{* *}$ & 19. $7^{*}$ & $33.1^{* *}$ & $4.7^{*}$ & $13.4^{* *}$ & $11.0^{* *}$ \\
\hline & \pm 1.1 & \pm 2.6 & \pm 2.4 & \pm 1.6 & \pm 1.1 & \pm 1.1 \\
\hline \multirow[t]{2}{*}{$\operatorname{TrCel} 5 A_{E R}-3$} & 18.9 & $20.5^{*}$ & $27.2^{* *}$ & $4.5^{*}$ & 16.2 & $12.0^{* *}$ \\
\hline & \pm 1.9 & \pm 3.4 & \pm 3.5 & \pm 1.4 & \pm 1.9 & \pm 1.2 \\
\hline
\end{tabular}

Relative values [\%] for sugar distribution in matrix polysaccharide fraction. Data analyzed by two-sided Student's t-test; **indicates a significant $\mathrm{P}<0.01 ;{ }^{*}$ indicates a significant $\mathrm{P}<0.05 ; \mathrm{n}=20$.

the staining did not reflect the expression level of the enzyme.

As already described, TrCel5A underwent proteolytic cleavage within the linker region when expressed in tobacco [34]. However, the truncated enzyme remains active against soluble substrates such as azoCMC or other $\beta$-glucans $[34,37]$. Comparing the two localization strategies, the apoplast targeting yielded the truncated form of $\operatorname{TrCel} 5 \mathrm{~A}$ alone, whereas retention in the ER yielded a mixture of the truncated and full-length enzyme, although the latter was a minor product. TrCel5A activity in the transgenic plants was determined by measuring the conversion of $4 \mathrm{MUC}$ into $4 \mathrm{MU}$, resulting in a maximum of $33 \mathrm{nmol} 4 \mathrm{MU} \mathrm{min}^{1} \mathrm{mg}^{-1}$ in the $\operatorname{TrCel} 5 \mathrm{~A}_{\mathrm{AP}}$ plants and $46 \mathrm{nmol} 4 \mathrm{MU} \mathrm{min}^{-1} \mathrm{mg}^{-1}$ in the TrCel5A plants. This probably reflects the relative scarcity in the number and quantity of proteases in the ER lumen compared to the apoplast [51].

As described previously, TrCel5A showed remarkable residual activity under physiological conditions typical for tobacco plants $\left(20-30^{\circ} \mathrm{C}, \mathrm{pH} 5.0\right)$ suggesting it potentially interferes with the synthesis of cell wall cellulose during normal plant growth and development [34]. Affirming our precedent findings, the TrCel5 $\mathrm{A}_{\mathrm{AP}}$ transgenic plants grew more slowly, germinated less frequently and showed a significant decrease in the amount of crystalline cellulose then wt. Despite the higher expression level of TrCel5A retained in the ER, no significant difference between $\operatorname{TrCel} 5 \mathrm{~A}_{\mathrm{ER}}$ and wt were detected for these traits. Endoglucanase expression targeted to the apoplast has the potential to interfere with endogenous cellulose synthesis, where ER retention should avoid it, because the cellulose synthesis takes place in the plasma membrane by the cellulose synthase complexes. After polymerization, the glucan chains are extruded into the extracellular space [9]. This corresponds to our observation that the content of crystalline cellulose is reduced in $\operatorname{TrCel} 5 \mathrm{~A}_{\mathrm{AP}}$ plants but not in TrCel5A $A_{\text {ER }}$ plants. However the role of endoglucanases during the synthesis of cell wall cellulose appears far more intricate. Plant endoglucanases such as KORRIGAN are necessary for the accumulation of sufficient cellulose and its absence leads to a cellulose deficiency and growth defects $[14,52]$. Recent studies have shown that the overexpression of KORRIGAN and other recombinant endoglucanases can also reduce the crystallinity of cellulose $[23,34,47]$.

The analysis of matrix polysaccharide composition of transgenic and wt tobacco plants revealed a significant reduction in the relative amounts of glucose, arabinose and rhamnose in the $\operatorname{TrCel} 5 \mathrm{~A}_{\mathrm{AP}}$ lines, but much higher levels of galactose and xylose. Plant GHs have been shown to remodel cell wall polysaccharides in the apoplastic space and during the transport of polysaccharide precursors through the Golgi apparatus [15]. Therefore, TrCel5A potentially interferes with the syntheses of Xyloglucan (XyG). However, TrCel5A is a strict endoglucanase and is only known to cleave $\beta 1,4$ linkages between glucopyranose units, while showing no activity against complex mixed glucans [37]. Thus, the degradation is likely to take place at an earlier stage of XyG synthesis, when the glucan chains are still undecorated. The higher levels of galactose and xylose would directly reflect these losses of glucose.

The relative level of glucose was also lower in the TrCel5 $\mathrm{A}_{\mathrm{ER}}$ lines, albeit not to the extent seen in the $\operatorname{TrCel} 5 \mathrm{~A}_{\mathrm{AP}}$ lines. Galactose levels were also higher, as in the $\operatorname{TrCel} 5 \mathrm{~A}_{\mathrm{AP}}$ plants, but xylose levels were lower in 
two of three tested lines. All $\mathrm{TrCel} 5 \mathrm{~A}_{\mathrm{AP}}$ plants had lower levels of mannose and one line also showed lower levels of arabinose and rhamnose. These changes in the matrix polysaccharide composition for $\operatorname{TrCel} 5 \mathrm{~A}_{E R}$ lines were not associated with a visible phenotype in contrast to the observed changes in the $\operatorname{TrCel} 5 \mathrm{~A}_{\mathrm{AP}}$ plants.

ER localization was used to prevent the enzyme from entering the Golgi apparatus where most hemicellulose and pectin synthesis takes place [53,54]. However, recent studies have shown that ER-localized fungal enzymes can still affect matrix polymer synthesis. This has been shown for the deferuloylation of arabinoxylans in $F$. arundinacea by using a fungal ferulic acid esterase A. Even if the detected enzyme values for Golgi apparatus localization - the place of the synthesis - were higher, significant cleavage was observed for ER retardation of the enzyme [33]. This may reflect the promiscuous behavior of KDEL-tagged proteins, which can in some cases enter the Golgi network from where they are later retrieved [55].

$\mathrm{XyG}$ is the most abundant hemicellulose in the primary cell walls of dicotyledonous plants, representing up to $30 \%$ by weight [12]. In most dicots the main form is fucogalacto-XyG, but arabinogalacto-XyG is more abundant in solanaceous plants and monocots $[13,56]$. In fucogalacto-XyG, galactose is transferred to the xylosyl residue and then substituted with fucose, whereas in arabinogalacto-XyG galactose or arabinose can be transferred to the xylosyl residue [13]. The scarcity of glucose could then lead to the reduced levels of xylose in the matrix polysaccharides of $\mathrm{TrCel} 5 \mathrm{~A}_{\mathrm{ER}}$ plants. In contrast, xylose levels were normal in the $\mathrm{TrCel} 5 \mathrm{~A}_{\mathrm{AP}}$ lines. Interestingly, galactose levels were elevated in all the plants. Despite these differences in biochemistry, there was no significant morphological or developmental change in the $T r C e l 5 A_{E R}$ plants, which is consistent with previous observations of mutant plants with changes in the XyG side chain composition [57].

The remaining amount of crystalline cellulose was measured in the tobacco leaves after digestion with a commercial cellulase preparation, revealing a two-fold reduction in $\operatorname{TrCel} 5 \mathrm{~A}_{\mathrm{AP}}$ plants after $8 \mathrm{~h}$ compared to wt and $\operatorname{TrCel} 5 \mathrm{~A}_{\mathrm{ER}}$ plants. After $65 \mathrm{~h}$ however, all three lines contained the same relative amounts of residual cellulose, showing that degradation was accelerated but not enhanced overall in the TrCel5 $\mathrm{A}_{\mathrm{AP}}$ plants. Quantitative effects were ruled out by carefully selecting transgenic plants of both lines with similar overall enzyme expression levels, and we found no overall difference between the transgenic and wt lines. Endoglucanases produced in planta have previously been shown to make the plant cell wall less recalcitrant to hydrolysis [23]. Accordingly, our results confirmed a significant reduction in the levels of crystalline cellulose in $\operatorname{TrCel} 5 \mathrm{~A}_{\mathrm{AP}}$ plants followed by accelerated hydrolysis.
The altered matrix polysaccharide fraction of the TrCel5A $A_{E R}$ plants appeared to have little impact on the enzymatic hydrolysis of leaf material, which was similar to the profile in wt leaves. This may reflect the relatively simple assay substrate, which does not consider the impact of lignin due to its low abundance in leaves compared to stems and roots [58]. The modification of cell wall hemicellulose using hydrolytic enzymes can promote lignocellulose degradation by reducing the amount of crosslinking between polymers [22,24,33].

\section{Conclusions}

The heterologous expression of the mesophilic endoglucanase TrCel5A had a significant impact on the composition of plant cell wall polysaccharides, although the precise changes were dependent on the subcellular localization of the enzyme. The secreted enzyme notably reduced the content of crystalline cellulose and inhibited both growth and germination, whereas keeping the enzyme in the ER only altered the matrix phase polysaccharide composition without visible effects on plant development, suggesting a more important role of the crystalline cellulose for growth and development. This study obtained further insights on the impact of GHs on the plant and especially the cell wall polysaccharides, beneficial in designing crops to contribute to novel sustainable and renewable resources.

\section{Methods}

\section{Construction of plant expression vectors}

Cloning of plant expression vectors was done according to the previously described procedure [34]. The gene of T. reesei Endoglucanase TrCel5A (EGR51020.1, EMBLCDS) was amplified by PCR using the forward primer cel5A (5' TCC ATG GCA CAG CAG ACT GTC TGG GGC $3^{\prime}$ ) and the reverse primer cel5A rv (5' TGC GGC CGC CTT TCT TGC GAG ACA CG 3'). These primers avoided the first 21 codons of the gene which contain the fungal signal peptide. The purified PCR product was transferred to the pCR2.1 vector (Invitrogen, Darmstadt, Germany) by TA-cloning to generate the construct pCR2.1 $\operatorname{TrCel} 5 \mathrm{~A}$. Following digestion with $\mathrm{NcoI}$ and NotI, the released cassette was then inserted into the NcoI NotI linearized vector pTRAkc-ER.

\section{In planta expression of TrCel5A}

Agrobacterium tumefaciens strain GV3101::pMP90RK was transformed with the above described vectors [59] by electroporation [60]. Colonies were transferred to liquid YEP medium (1\% (w/v) Bacto tryptone; $1 \%(\mathrm{w} / \mathrm{v})$ yeast extract; $0.5 \%(\mathrm{w} / \mathrm{v}) \mathrm{NaCl} ; \mathrm{pH} 7.0)$ containing kanamycin $\left(50 \mathrm{mg} \mathrm{ml}^{-1}\right)$, rifampicin $\left(50 \mathrm{mg} \mathrm{ml}^{-1}\right)$ and carbenicillin $\left(100 \mathrm{mg} \mathrm{ml}^{-1}\right)$ for $36-40 \mathrm{~h}\left(26^{\circ} \mathrm{C}, 180 \mathrm{rpm}\right)$ for selection. The suspensions were then supplemented with 
$10 \mu \mathrm{M}$ acetosyringone, $10 \mathrm{mM}$ MES ( $\mathrm{pH}$ 5.6) and $10 \mathrm{mM}$ glucose, and incubated for another $20 \mathrm{~h}$. The $\mathrm{OD}_{600}$ of the culture was adjusted to 1.0 with $2 \times$ infiltration medium $(0.86 \%(\mathrm{w} / \mathrm{v})$ MS salts, $10 \%(\mathrm{w} / \mathrm{v})$ sucrose, $0.36 \%(\mathrm{w} / \mathrm{v})$ glucose, $\mathrm{pH}$ 5.6) and supplemented with $200 \mu \mathrm{M}$ acetosyringone prior to incubation for $45 \mathrm{~min}$ at room temperature. Transgenic tobacco lines were generated (N. tabacum L. cv. Petit Havana SR1) using the leaf disc transformation method [36]. T0 plants were grown on Murashige-Skoog medium containing $100 \mathrm{mg} / \mathrm{L}$ kanamycin and $200 \mathrm{mg} / \mathrm{L}$ Claforan, and subsequently transferred to soil in the greenhouse. T1 lines showing Mendelian segregation consistent with a single locus insertion were used for all further assays.

\section{Light and electron microscopy}

Thin sections of $10 \mu \mathrm{m}$ from transgenic and wild type leaf material were prepared using a Leica Cryostat Microtome and incubated in acetone for $30 \mathrm{~min}$ at room temperature. The thin section were blocked in phosphate buffered saline (PBS) containing 1\% (v/v) Goat serum (Sigma-Aldrich, Seelze, Germany) and subsequently incubated with the primary antibody (diluted (1:50) in PBS containing 1\% (v/v) Goat serum) for $45 \mathrm{~min}$. Following three washing steps in PBS containing 0.05\% (v/v) Tween-20 (Roth, Karlsruhe, Germany), the thin section were incubated with the secondary antibody (diluted (1:200) in PBS containing 1\% (v/v) Goat serum for $45 \mathrm{~min}$ ). After three washing steps in PBS containing $0.05 \%(\mathrm{v} / \mathrm{v})$ Tween-20, the sections were analyzed using a Leica microscope.

For electron microscopy, tobacco leaves were fixed in $4 \%(\mathrm{w} / \mathrm{v})$ paraformaldehyde and $0.5 \%(\mathrm{v} / \mathrm{v})$ glutaraldehyde in $0.1 \mathrm{M}$ phosphate buffer ( $\mathrm{pH} 7.4$ ), and then embedded in resin. Sections showing silver interference were collected on copper grids [61]. The primary antibody (diluted 1:50 in PBS) was detected with secondary antibodies (diluted 1:200 in PBS) labeled with $10 \mathrm{~nm}$ gold particles. Subsequently ultra-thin sections were stained with $2 \%(\mathrm{w} / \mathrm{v})$ aqueous uranyl acetate and observed using a Philips EM-400 transmission electron microscope (Philips, Eindhoven, The Netherlands).

\section{Protein extraction and purification}

Transgenic leaves were ground in liquid nitrogen and homogenized in PBS; pH 7.0 supplemented with $1 \mathrm{mM}$ phenylmethylsulfonyl fluoride (PMSF). The extract was centrifuged at $15,000 \times \mathrm{g}$ for $20 \mathrm{~min}$ at $4^{\circ} \mathrm{C}$ followed by filtration. The His6-tagged protein was purified from TSP by Ni-NTA agarose affinity chromatography (Qiagen, Hilden, Germany). Imidazole was removed using a Roti ${ }^{\circledR}$ Spin column (Roth, Karlsruhe, Germany) with a molecular weight cut off $10 \mathrm{kDa}$. Total protein levels were determined using the Bradford method [62] with bovine serum albumin (Roth, Karlsruhe, Germany) as the standard.

\section{Polyacrylamide gel electrophoresis, and western blot}

Protein samples were separated by SDS-PAGE in a $12 \%$ polyacrylamide gel. For Western blot analysis, separated proteins were electro-transferred (60 $\mathrm{min}, 250 \mathrm{~mA})$ to nitrocellulose membranes, blocked for $1 \mathrm{~h}$ at room temperature with $5 \%(\mathrm{w} / \mathrm{v})$ skimmed milk in PBS, and then probed first with a monoclonal Penta His Antibody (Qiagen, Hilden, Germany) and then with a monoclonal alkaline phosphatase-conjugated goat anti-mouse antibody (Dianova, Hamburg, Germany). The signal was visualized with nitroblue tetrazolium chloride/5-bromo-4-chloro3'-indolyphosphate p-toluidine salt (NBT/BCIP) (Roth, Karlsruhe, Germany).

\section{Endoglucanase assays}

Endoglucanase activity in crude plant extract was determined by the conversion of 4-MUC into 4MU, as described previously [63]. Samples were run in triplicate, with each sample $(1-5 \mu \mathrm{l})$ assayed in $100 \mu \mathrm{l}$ buffer (50 mM sodium acetate, $\mathrm{pH} 4.8,0.5 \mathrm{mM}$ 4-MUC) in a 96-well plate. Plates were covered with adhesive lids to prevent evaporation and incubated for $60 \mathrm{~min}$ at $50^{\circ} \mathrm{C}$. The reaction was stopped by adding $100 \mu \mathrm{l} 0.15 \mathrm{M}$ glycine, $\mathrm{pH}$ 10.0. The fluorescence was determined using Tecan Infinite M200 (excitation wavelength of $360 \mathrm{~nm}$, emission wavelength $465 \mathrm{~nm}$ ). Fluorescence data of endoglucanase activity from plants with both localization for TrCel5A were corrected by subtraction of the average data from wt crude plant extract $(n=3)$. Conversion rates were calculated from corrected data based on a series of $4 \mathrm{MU}$ standards $(1-10 \mathrm{nM})$.

\section{Cell wall sugar analysis}

Cellulose was extracted from leaf tissue taken from 6-7 week-old plants. Ten samples were taken from each transgenic line and from wt tobacco plants. Alcoholinsoluble residues were prepared from frozen leaf tissue by grinding $50 \mathrm{mg}$ of sample to a fine powder under liquid nitrogen, and isolating the plant cell walls by washing with different organic solvents [39]. Starch was removed by enzymatic digestion with $\alpha$-amylase and pullulanase (Sigma-Aldrich, Seelze, Germany). The remaining AIR was extracted with acetone, dried and weighed. Matrix polysaccharide composition was determined with $\mathrm{GC} /$ MS measurement according to Foster et al. [38]. The crystalline cellulose content was determined [41] after hydrolyzing the non-crystalline cellulose with acetic and nitric acid. The remaining crystalline cellulose residues were hydrolyzed with $72 \%(\mathrm{w} / \mathrm{v})$ sulfuric acid allowing the remaining glucose to be measured using the anthrone assay [64]. 
Significant differences from wt were determined using a Student $t$-test ( $\mathrm{p}$ value $\leq 0.01$ )

\section{Conversion of transgenic tobacco leaf material}

To estimate the glucan content, tobacco leaf material was hydrolyzed in sulfuric acid and the carbohydrates were determined using the anthrone assay [64]. For the conversion of leaf material, 50-100 mg of fresh tobacco leaf tissue was ground to a powder in liquid nitrogen and resuspended in buffer $(50 \mathrm{mM}$ sodium acetate, $\mathrm{pH}$ 4.8) containing 15 Filter paper units (FPU) CTec2 (Novozymes A/S, Denmark) per g glucan. The reaction was terminated by boiling for $10 \mathrm{~min}$ and subsequently centrifugation at $10.000 \times \mathrm{g}$. To determine the rate of hydrolysis, the remaining crystalline cellulose was measured according to the previously described methods. Values were calculated from three independent experiments, each containing three replicates.

\section{Availability of supporting data}

The data sets supporting the results of this article are included within the article and its additional files.

\section{Additional file}

\begin{abstract}
Additional file 1: Supplemental Figure S1: Schematic presentation of the plant expression cassettes for differential targeting of

TrCel5A. The CaMV promoter (P35SS) and terminator signal (pA35S) are indicated in light blue. 5'-UTR of chalcone synthase (CHS), the His6 coding sequence (His6) is indicated in blue. The plant codon-optimized leader peptide (LPH) derived from the heavy chain of the murine mAb24 is depicted in green. $\mathrm{LPH}$ achieves the secretion of the recombinant protein to the apoplast (A). Additionally added C-terminal KDEL signal indicated in red retards the protein to the ER (B). Arrows label the binding site for primer to amplify the CaMV 3555 expression cassette. (C) Western blot analysis for transient expression of TrCel5A for ER and apoplast localization compared with catalytic domain of $\operatorname{TrCel5A}(\mathrm{cd})$. Supplemental Figure S2: Monitoring transgenic tobacco plant growth over time. Tobacco plants were grown in soil (Einheitserde ${ }^{\oplus}$ Typ ED73) with 16/8 h light/dark cycle $(500 \mu \mathrm{mol} \mathrm{s}-1 \mathrm{~m} 2, \lambda=400-700 \mathrm{~nm}$ ) and daily watering. Additional fertilizer (WUXAL, $\sim 0,05 \% \mathrm{v} / \mathrm{v}$ ) was used once after 40 days with the spilling water. Bars represent $20 \mathrm{~cm}$ length.
\end{abstract}

\footnotetext{
Abbreviations

4MU: 4-Methylumbelliferone; 4MUC: 4-Methylumbelliferyl $\beta$-D-cellobioside; AIR: Alcohol insoluble residues; AP: Apoplast; BCIP: 5 Bromo-4-chloro-3'indolyphosphate p-toluidine; CaMV: Cauliflower Mosaic Virus; CBM: Cellulose binding module; CMC: Carboxymethylcellulose; EG: Endoglucanase; ER: Endoplasmic reticulum; FPU: Filter paper unit; GC: Gas chromatography; GH: Glycosyl hydrolase; MES: 2-(N-morpholino) ethanesulfonic acid; MPS: Matrix polysaccharides; MS: Mass spectrometry; MS: Murashige and Skoog; NBT: Nitro-blue tetrazolium chloride; NTA: Nitrilotriacetic acid; PAGE: Polyacrylamide gel electrophoresisPBS: Phosphate buffered saline; PMSF: Phenyl-methylsulfonyl fluoride; SDS: Sodium dodecyl sulfate; TSP: Total soluble protein; UTR: Untranslated region; Wt: wild type; XyG: Xyloglycan; YEP: Yest extract peptone.
}

\section{Competing interests}

The authors declare that they have no competing interests.

\section{Authors' contribution}

HK designed and carried out the experiments, analyzed results and wrote the manuscript. MG carried out the analysis of the MPS in tobacco cell walls. $\mathrm{BU}$ assisted in the experimental design and reviewed the manuscript. RF and UC coordinated the study and reviewed the manuscript. All authors read and approved the final manuscript

\section{Acknowledgements}

This work was supported by the "Forschungsinitiative BioEnergie 2021 Forschung für die Nutzung von Biomasse" from the German Federal Ministry of Education and Research (BMBF), the Excellence Cluster "Tailor-made Fuels from Biomass", which is funded through the Excellence Initiative by the German federal and state governments to promote science and research at German universities and NRW-Strategieprojekt BiosC funded by the Ministry of Innovation, Science and Research of the German State of North Rhine-Westphalia. The authors thank Dr. Flora Schuster for producing the transgenic plants and Karolin Richter for generating the TEM pictures and Raimund Knauf for plant growth and preparation of high quality plant figures.

\section{Author details}

${ }^{1}$ Institute for Molecular Biotechnology, RWTH Aachen University, Worringer Weg 1, 52074 Aachen, Germany. ${ }^{2}$ Institute for Botany and Molecular Genetics, RWTH Aachen University, Worringer Weg 3, 52074 Aachen, Germany. ${ }^{3}$ Institute of Bio- and Geosciences, IBG-2: Plant Sciences, Forschungszentrum Jülich, Leo- Brandt-Straße, 52425 Jülich, Germany. ${ }^{4}$ Fraunhofer Institute for Molecular Biology and Applied Ecology (IME), Forckenbeckstrasse 6, 52074 Aachen, Germany.

Received: 16 December 2014 Accepted: 29 January 2015 Published online: 13 February 2015

\section{References}

1. Simmons B, Loque D, Blanch H. Next-generation biomass feedstocks for biofuel production. Genome Biol. 2008;9:242.

2. Carroll A, Somerville C. Cellulosic Biofuels. Annu Rev Plant Biol. 2009:60:165-82.

3. Harris PJ, Stone BA. Chemistry and Molecular Organization of Plant Cell Walls. In: Biomass Recalcitrance. Oxford: Blackwell Publishing Ltd; 2009. p. 61-93.

4. Burton RA, Gidley MJ, Fincher GB. Heterogeneity in the chemistry, structure and function of plant cell walls. Nat Chem Biol. 2010;6:724-32.

5. Himmel ME, Picataggio SK. Our Challenge is to Acquire Deeper Understanding of Biomass Recalcitrance and Conversion. In: Biomass Recalcitrance. Oxford: Blackwell Publishing Ltd; 2009. p. 1-6.

6. Sims REH, Mabee W, Saddler JN, Taylor M. An overview of second generation biofuel technologies. Bioresour Technol. 2010;101:1570-80.

7. Abramson M, Shoseyov O, Shani Z. Plant cell wall reconstruction toward improved lignocellulosic production and processability. Plant Sci. 2010;178:61-72.

8. McCann M, Rose J. Blueprints for Building Plant Cell Walls. Plant Physiol. 2010;153(2):365.

9. Endler A, Persson S. Cellulose Synthases and Synthesis in Arabidopsis. Mol Plant. 2011:4:199-211.

10. Delmer DP. Cellulose Biosynthesis: Exciting Times for A Difficult Field of Study. Annu Rev Plant Physiol Plant Mol Biol. 1999:50:245-76.

11. Perrin R, Wilkerson C, Keegstra K. Golgi enzymes that synthesize plant cell wall polysaccharides: finding and evaluating candidates in the genomic era. In: Carpita NC, Campbell M, Tierney M, editors. Plant Cell Walls SE - 7. Netherlands: Springer; 2001. p. 115-30.

12. Scheller HV, Ulvskov P. Hemicelluloses. Annu Rev Plant Biol. 2010;61:263-89.

13. Pauly M, Gille S, Liu L, Mansoori N, Souza A, Schultink A, et al. Hemicellulose biosynthesis. Planta. 2013;238:627-42

14. Takahashi J, Rudsander UJ, Hedenstrom M, Banasiak A, Harholt J, Amelot N, et al. KORRIGAN1 and its Aspen Homolog PttCel9A1 Decrease Cellulose Crystallinity in Arabidopsis Stems. Plant Cell Physiol. 2009;50:1099-115.

15. Minic Z. Physiological roles of plant glycoside hydrolases. Planta. 2008;227:723-40.

16. Shani Z, Dekel M, Roiz L, Horowitz M, Kolosovski N, Lapidot S, et al. Expression of endo-1,4- $\beta$-glucanase (cel1) in Arabidopsis thaliana is associated with plant growth, xylem development and cell wall thickening. Plant Cell Rep. 2006:25:1067-74. 
17. Elkins JG, Lochner A, Hamilton-Brehm SD, Davenport KW, Podar M, Brown SD, et al. Complete Genome Sequence of the Cellulolytic Thermophile Caldicellulosiruptor obsidiansis OB47T. J Bacteriol. 2010;192(22):6099-100.

18. Hood EE, Devaiah SP, Fake G, Egelkrout E, Thomas TK, Requesens DV, et al. Manipulating corn germplasm to increase recombinant protein accumulation. Plant Biotechnol J. 2012;10:20-30.

19. Verma D, Kanagaraj A, Jin S, Singh ND, Kolattukudy PE, Daniell $H$. Chloroplast-derived enzyme cocktails hydrolyse lignocellulosic biomass and release fermentable sugars. Plant Biotechnol J. 2010;8:332-50.

20. Pen J, Molendijk L, Quax WJ, Sijmons PC, van Ooyen AJJ, van den Elzen PJM, et al. Production of Active Bacillus licheniformis Alpha-Amylase in Tobacco and its Application in Starch Liquefaction. Nat Biotech. 1992;10:292-6.

21. Czihal A, Conrad B, Buchner P, Brevis R, Azim Farouk A, Manteuffel R, et al. Gene Farming in Plants: Expression of a Heatstable Bacillus Amylase in Transgenic Legume Seeds. J Plant Physiol. 1999;155:183-9.

22. Pogorelko G, Fursova O, Lin M, Pyle E, Jass J, Zabotina OA. Post-synthetic modification of plant cell walls by expression of microbial hydrolases in the apoplast. Plant Mol Biol. 2011;77:433-45

23. Brunecky R, Selig M, Vinzant T, Himmel M, Lee D, Blaylock M, et al. In planta expression of $A$. cellulolyticus Cel5A endocellulase reduces cell wall recalcitrance in tobacco and maize. Biotechnol Biofuels. 2011:4:1.

24. Zhang D, VanFossen A, Pagano R, Johnson J, Parker M, Pan S, et al. Consolidated Pretreatment and Hydrolysis of Plant Biomass Expressing Cell Wall Degrading Enzymes. BioEnergy Res. 2011;4:276-86.

25. Taylor LE, Dai Z, Decker SR, Brunecky R, Adney WS, Ding SY, et al. Heterologous expression of glycosyl hydrolases in planta: a new departure for biofuels. Trends Biotechnol. 2008;26:413-24.

26. Sainz M. Commercial cellulosic ethanol: The role of plant-expressed enzymes. Vitr Cell Dev Biol Plant. 2009;45:314-29.

27. Garvey M, Klose H, Fischer R, Lambertz C, Commandeur U. Cellulases for biomass degradation: Comparing recombinant cellulase expression platforms. Trends Biotechnol. 2013;10:581-93.

28. Herbers K, Wilke I, Sonnewald U. A Thermostable Xylanase from Clostridium thermocellum Expressed at High Levels in the Apoplast of Transgenic Tobacco Has No Detrimental Effects and Is Easily Purified. Nat Biotech. 1995;13:63-6.

29. Dai Z, Hooker BS, Quesenberry RD, Thomas SR. Optimization of Acidothermus cellulolyticus endoglucanase (E1) production in transgenic tobacco plants by transcriptional, post-transcription and post-translational modification. Transgenic Res. 2005;14:627-43.

30. Klose H, Röder J, Girfoglio M, Fischer R, Commandeur U. Hyperthermophilic endoglucanase for in planta lignocellulose conversion. Biotechnol Biofuels. 2012;1:63.

31. DeO BM, Langdon T, Hauck B, Alton S, Morris P. Maniplating the phenolic acid content and digestibility of italian ryegrass (Lolium multiflorum)b y vacuolar-targeted epession of a fungal ferulic acid esterase. Appl Biochem Biotechnol. 2006;130:416-26.

32. Buanafina MM De O, Langdon T, Hauck B, Dalton S, Morris P. Expression of a fungal ferulic acid esterase increases cell wall digestibility of tall fescue (Festuca arundinacea). Plant Biotechnol J. 2008;6:264-80.

33. Buanafina MM De O, Langdon T, Hauck B, Dalton S, Timms-Taravella E, Morris P. Targeting expression of a fungal ferulic acid esterase to the apoplast, endoplasmic reticulum or golgi can disrupt feruloylation of the growing cell wall and increase the biodegradability of tall fescue (Festuca arundinacea). Plant Biotechnol J. 2010;8:316-31.

34. Klose H, Günl M, Usadel B, Fischer R, Commandeur U. Ethanol inducible expression of a mesophilic cellulase avoids adverse effects on plant development. Biotechnol Biofuels. 2013:6:53.

35. Vaquero C, Sack M, Chandler J, Drossard J, Schuster F, Monecke M, et al. Transient expression of a tumor-specific single-chain fragment and a chimeric antibody in tobacco leaves. Proc Natl Acad Sci. 1999;96:11128-33

36. Horsch RB, Fry JE, Hoffman NL, Rogers SG, Fraley RT. A Simple and General Method for Transferring Genes into Plants. Science (80). 1985;227:1229-31.

37. Nakazawa H, Okada K, Kobayashi R, Kubota T, Onodera T, Ochiai N, et al. Characterization of the catalytic domains of Trichoderma reesei endoglucanase I, II, and III, expressed in Escherichia coli. Appl Microbiol Biotechnol. 2008;81:681-9.
38. Demesure B, Sodzi N, Petit RJ. A set of universal primers for amplification of polymorphic non-coding regions of mitochondrial and chloroplast DNA in plants. Mol Ecol. 1995;4:129-34

39. Foster CE, Martin TM, Pauly M. Comprehensive compositional analysis of plant cell walls (lignocellulosic biomass) part II: carbohydrates. J Vis Exp. 2010;37:1837.

40. Albersheim P, Nevins DJ, English PD, Karr A. A method for the analysis of sugars in plant cell-wall polysaccharides by gas-liquid chromatography. Carbohydr Res. 1967:5:340-5.

41. Updegraff DM. Semimicro determination of cellulose in biological materials. Anal Biochem. 1969;32:420-4

42. Fischer R, Stoger E, Schillberg S, Christou P, Twyman RM. Plant-based production of biopharmaceuticals. Curr Opin Plant Biol. 2004;7:152-8

43. Streatfield S. Approaches to achieve high-level heterologous protein production in plants. Plant Biotechnol J. 2007;5:2-15.

44. Petersen K, Bock R. High-level expression of a suite of thermostable cell wall-degrading enzymes from the chloroplast genome. Plant Mol Biol. 2011;76:311-21.

45. Abdeev RM, Musiichuk KA, Goldenkova IV, Sotchenkov DV, Salekhi Dzhuzani GR, Alyavina AK, et al. Morphology and Phytohormone Content in Transgenic Tobacco Plants Expressing Bacterial Thermostable Cellulase. Russ J Plant Physiol. 2004;51:642-7.

46. Lopez-Casado G, Urbanowicz BR, Damasceno CMB, Rose JKC. Plant glycosyl hydrolases and biofuels: a natural marriage. Curr Opin Plant Biol. 2008;11:329-37.

47. Maloney VJ, Mansfield SD. Characterization and varied expression of a membrane-bound endo-b-1,4-glucanase in hybrid poplar. Plant Biotechnol J. 2010;8:294-307.

48. Mahadevan S, Wi S, Kim Y, Lee K, Bae H-J. In planta differential targeting analysis of Thermotoga maritima Cel5A and CBM6-engineered Cel5A for autohydrolysis. Transgenic Res. 2011;20:877-86.

49. Kim S, Lee D-S, Choi I, Ahn S-J, Kim Y-H, Bae H-J. Arabidopsis thaliana Rubisco small subunit transit peptide increases the accumulation of Thermotoga maritima endoglucanase Cel5 $\mathrm{A}$ in chloroplasts of transgenic tobacco plants. Transgenic Res. 2010;19:489-97.

50. Ziegelhoffer T, Raasch JA, Austin-Phillips S. Expression of Acidothermus cellulolyticus E1 endo-beta-1,4-glucanase catalytic domain in transplastomic tobacco. Plant Biotechnol J. 2009;7:527-36.

51. Beyene $\mathrm{G}$, Foyer $\mathrm{CH}$, Kunert $\mathrm{KJ}$. Two new cysteine proteinases with specific expression patterns in mature and senescent tobacco (Nicotiana tabacum L.) leaves. J Exp Bot. 2006;57:1431-43.

52. Mølhøj M, Pagant S, Höfte H. Towards Understanding the Role of Membrane-bound Endo- $\beta-1,4-$ glucanases in Cellulose Biosynthesis. Plant Cell Physiol. 2002;43(12):1399-406.

53. Moore P, Staehelin LA. Immunogold localization of the cell-wall-matrix polysaccharides rhamnogalacturonan I and xyloglucan during cell expansion and cytokinesis inTrifolium pratense L.; implication for secretory pathways. Planta. 1988;174:433-45.

54. Staehelin LA, Moore I. The Plant Golgi Apparatus: Structure, Functional Organization and Trafficking Mechanisms. Annu Rev Plant Physiol Plant Mol Biol. 1995;46:261-88.

55. Pelham HRB. The retention signal for soluble proteins of the endoplasmic reticulum. Trends Biochem Sci. 1990;15:483-6.

56. Ring SG, Selvendran RR. An arabinogalactoxyloglucan from the cell wall of Solanum tuberosum. Phytochemistry. 1981;20:2511-9.

57. Jensen JK, Schultink A, Keegstra K, Wilkerson CG, Pauly M. RNA-Seq Analysis of Developing Nasturtium Seeds (Tropaeolum majus): Identification and Characterization of an Additional Galactosyltransferase Involved in Xyloglucan Biosynthesis. Mol Plant. 2012;5(5):984-92.

58. Van Dyk JS, Pletschke BI. A review of lignocellulose bioconversion using enzymatic hydrolysis and synergistic cooperation between enzymesFactors affecting enzymes, conversion and synergy. Biotechnol Adv. 2012:30:1458-80.

59. Koncz C, Schell J. The promoter of T-DNA gene Scontrols the tissue-specific expression of chimaeric genes carried by a novel type of Agrobacterium binary vector. Mol Gen Genet MGG. 1986;204:383-96.

60. Shen W, Forde BG. Efficient transformation of Agrobacterium spp. by high voltage electroporation. Nucleic Acids Res. 1989;17:8385.

61. Arcalis E, Marcel S, Altmann F, Kolarich D, Drakakaki G, Fischer R, et al. Unexpected Deposition Patterns of Recombinant Proteins in PostEndoplasmic Reticulum Compartments of Wheat Endosperm. Plant Physiol. 2004;136(3):3457-66. 
62. Bradford M. A rapid and sensitive method for the quantitation of microgram quantities of protein utilizing the principle of protein-dye binding. Anal Biochem. $1976 ; 72: 248-54$.

63. Ziegelhoffer T, Raasch JA, Austin-Phillips S. Dramatic effects of truncation and sub-cellular targeting on the accumulation of recombinant microbial cellulase in tobacco. Mol Breed. 2001;8:147-58.

64. Scott TA, Melvin EH. Determination of Dextran with Anthrone. Anal Chem. 1953;25:1656-61.

Submit your next manuscript to BioMed Central and take full advantage of:

- Convenient online submission

- Thorough peer review

- No space constraints or color figure charges

- Immediate publication on acceptance

- Inclusion in PubMed, CAS, Scopus and Google Scholar

- Research which is freely available for redistribution 